\title{
RESEARCHING SLOVENIAN EMIGRATION FROM THE PERSPECTIVE OF GENDERED MIGRATION
}

\author{
Mirjam MILHARČIČ HLADNIK'
}

COBISS 1.02

\begin{abstract}
Researching Slovenian Emigration from the Perspective of Gendered Migration The article presents how Slovenian women emigrants and women immigrants to Slovenia have become an important part of migration studies in Slovenia. The research has focused on gendered migration and revealed different ways of structuring power relationships, social practices and institutions organized according to the gender principle. The article also focuses on methodological development and emphasises the narrative and autobiographical approaches, which brought the voices of women migrants from the past and the present to the analysis of migration, thus enriching various disciplines with personal experiences, individual interpretations and the variety of emotions of women on the move.
\end{abstract}

KEY WORDS: gender, migration, Slovenian women migrants, methodology

\section{IZVLEČEK}

\section{Raziskovanje slovenskega izseljenstva v luči spolno obeleženih migracij}

Članek predstavlja, kako so izseljenke iz Slovenije in priseljenke v Slovenijo postale pomemben del migracijskih raziskav Inštituta za slovensko izseljenstvo in migracije ter drugih institucij. Raziskave spolno obeleženih migracij so namreč razkrile tako različne načine strukturiranja razmerij moči, družbenih praks in institucij, organiziranih po spolnem načelu, kot subjektivne procese konstrukcije identitet v kontekstu migracij. Članek pri osredotočanju na metodološki razvoj poudarja narativni in avtobiografski pristop, ki je $v$ analizo migracij vnesel glasove nekdanjih in sedanjih migrantk ter različne discipline obogatil z osebnimi izkušnjami, individualnimi interpretacijami in s paleto čustev žensk na poti.

KLJUČNE BESEDE: spol, migracija, slovenske migrantke, metodologija

PhD in Sociology, Associate Professor, University of Nova Gorica, Senior Fellow, Slovenian Migration Institute, SRC SASA, Novi trg 2, SI-1000 Ljubljana; hladnik@zrc-sazu-si - The author would like to acknowledge that the article was written in the framework of research projects »Socialna, gospodarska in kulturna zgodovina slovenskega izseljenstva 1870-1945 (JP-7167), »Socialna, gospodarska in kulturna zgodovina slovenskega izseljenstva 1945-1991 (JP-8246) and research core funding »Narodna in kulturna identiteta slovenskega izseljenstva v kontekstu raziskovanja migracij« (P5-0070) financially supported by the Slovenian Research Agency. 


\section{INTRODUCTION ${ }^{1}$}

In understanding and studying the historical and contemporary aspects of migration, women for a long time existed merely as passive companions of migrants or as the ones that stayed at home. In discussing migrant labour and the migrant economy, women and children were presented exclusively as dependent family members separated from the sphere of wage labour. Although Ernst G. Ravenstein pointed out the differences in the gender composition of migrations as early as 1885, and even claimed that women are more migratory than men, especially when it comes to shorter distances (Ravenstein 1885: 196), precisely a hundred years would pass before women would become the topic of migration studies. The scientific study of women migrants and female wage labour in the context of migration began only a little more than three decades ago. The turning point was "Women in Migration", a 1984 special issue of International Migration Review, which was devoted to female migration, and the global appeal to researchers in various disciplines to begin studying migration as a gendered phenomenon. After thirty years, we can say that this appeal had an effect on numerous researchers in various disciplines: political science, anthropology, geography, history, law, psychology, sociology, ethnology and women's studies all over the world. With the crystallisation of the female or gender perspective, migrations were presented through complicated structures of family decisions, intimate considerations and tightly knit personal and family ties of both genders. In particular, it turned out that the proportion of women migrants was and still is quite high and that in numerous cases women are the main breadwinners. The new trends in migration and its feminisation are part of the global and transnational processes. Barbara Ehrenreich and Arlie R. Hochschild (2003: 5) cite the following data:

From 1950 to 1970, for example, men predominated in labour migration to northern Europe from Turkey, Greece, and North Africa. Since then, women have been replacing men. In 1946, women were fewer than 3 percent of the Algerians and Moroccans living in France; by 1990, they were more than 40 percent. Overall, half of the world's 120 million legal and illegal migrants are now believed to be women. Patterns of international migration vary from region to region, but women migrants from a surprising number of sending countries actually outnumber men, sometimes by a large margin.

The feminisation of migration has become a concept without which we cannot discuss global migration. It refers to the high proportion of women among all migrants and also the greater visibility of female migrants, who, like women in general, have been a historically overlooked, ignored and invisible category. Studies have shown

1 This article is an updated version of a chapter in the book Raziskovanje slovenskega izseljenstva: vidiki, pristopi, vsebine / Slovenian emigration research: aspects, approaches, substance (eds. Janja Žitnik Serafin, Aleksej Kalc 2017, 67-83). 
that there was a high level of female migration in the past and that women were in fact predominant in some migration flows, periods and regions, while men predominated in others - a rule that also holds today (Donato, Gabaccia 2015). The characteristics of gendered migration change constantly, depending on socio-economic and political circumstances, conditions on the labour market, migrant social and communications networks and the visibility and invisibility of (female) labour. In addition to the changed view on the gender composition of migration in the past and the present that shows women as mass actors, research conducted over the last thirty years has presented various aspects of migration and broadened the very understanding of migration and migration phenomena.

In their research of gendered migration, numerous research projects focused on the following topics: wage labour of women migrants and its consequences for the traditional gender division of labour; the subjective experiences of women migrants and their interpretations of migration processes, integration processes and discrimination; social constructions of identities and subjectivities; the role of women in migrant communities and diasporas, refugee centres and temporary accommodation; engagement in self-organised structures, social and support networks; the complex roles of women migrants in the processes of transnational motherhood and parenthood and the survival and emotional strategies of women on both sides of the migration process - the women that leave and the women that stay behind; discrimination practices at the intersection of gender, ethnicity, religion and class; the analysis of victimisation discourse, in which women migrants are presented and studied exclusively as victims of human trafficking, the sex industry and family and structural violence; the role of women migrants in preserving and changing ethnic, religious and cultural identities; and more.

The process of discovering the historical and contemporary presence of women in migration and taking into account gender as a social generator of power relations and discrimination has contributed to the enrichment of numerous disciplines and the development of many interdisciplinary relations and methodological approaches. Below, I will first outline the characteristics of female migration in the Slovenian ethnic territory that have been studied to date and then present the methods used to study Slovenian female emigrants and gendered migration in Slovenia.

\section{WOMEN MIGRANTS IN THE SLOVENIAN ETHNIC TERRITORY AND SLOVENIAN RESEARCH}

The presence of women in Slovenian emigration is visible both in the mass emigration which took place before 1940 and later. For the period before 1940, Marjan Drnovšek collected some interesting examples to show how the diversity and intensity of women's migration should be seen in the different regional and time contexts (Drnovšek 2003: 31-33). While approximately 35 percent of the migrants 
in the Austrian migration wave taken as a whole were women, for some parts of the Slovenian ethnic territory the figures are quite different. For example, in 1892 women accounted for 21 percent of migrants from Carniola but 31 percent from the Kočevje region. In Germany, nearly 30 percent of migrants who declared Slovene as their mother tongue in 1900 were women, but in 1939 they accounted for 45 percent of Slovenian migrants. In seasonal migration from the Prekmurje region in eastern Slovenia, Drnovšek estimated that women accounted for 29 percent of migrants in 1929, 36 percent in 1930 and 41 percent in 1931. There were regions with less women migrants and parts of regions with very high numbers, like a cluster of villages in the Goriška region and the town of Domžale with its neighbouring villages.

This approximate estimation refers to various phenomena and development stages of individual migration flows in different political and administrative frameworks. It also has to be understood in the context of the absence of women in stateconducted statistical and other bureaucratic surveys of female labour, due to which there are and can be no data. Sheila Rowbotham (2001: xvi) explains why the type of wage labour that has always been performed by the largest number of women was always left out of historical, statistical and demographic surveys:

One reason for the lack of visibility has been the nature of female migrants' occupations. In many cases they went into domestic service or served as wet nurses - activities which have never been regarded within the prevailing definitions of "work" or the "economy" and have thus defied statistical reckoning. This is a gendered obscurity in a double sense. The women leave no traces because they are female and because the framework of who is to be seen has been biased towards the male.

Despite this, we know that in the Slovenian ethnic territory there were distinctly female migrant flows in which women migrated for work and were often also the breadwinners. In the period before 1940, three types of wage labour or occupations stand out: female servants and care workers from the entire territory who migrated to cities near and far, such as Zagreb, Belgrade, Skopje, Rome, Udine, or Milan, or to far-away countries such as the US, Germany, France and England (Kalc 2004; Drnovšek 2001; Mlekuž 2004); they included the least known and researched straw hat makers from the area of Domžale and Mengeš, who worked as seasonal migrants across the entire Habsburg Monarchy and emigrated to USA cities, while some of the returnees owned straw hat factories and workshops in Domžale ${ }^{2}$ (Roškar 2014); and the best known and literarily represented Aleksandrinke (Alexandrian women), who worked as nannies, cooks, companions, wet nurses and house servants, and migrated from the Goriška region to Egypt, where they stayed a year or two or even

2 Despite being less studied, the topic of women in straw hat making is represented at the local level, since it is included in the permanent collection of the Straw Hat Museum in Domžale, where they also provide presentations about female straw hat makers from Domžale in New York. 
several decades (Makuc 1994; Barbič, Miklavčič Brezigar 1999; Koprivec 2013; Milharčič Hladnik 2015).

There are no such estimates for the period after 1945. Women were part of the mass emigration for "temporary work abroad" or temporary migrant work, which was the official term for economic migration to Austria, Germany, Switzerland, Sweden and other Northern European countries after 1968. We have no detailed data on the gender composition of temporary migrant work, but we do know that, after family reunification, one's "temporary residence abroad" often changed into a permanent one. ${ }^{3}$ According to the available data, today's care workers are mostly commuters who perform paid domestic or care work in the border towns of Italy and Austria (Hrženjak 2014). This exclusively female activity, which is an interesting continuation of the historical activities in border areas, is conducted by female pensioners, college students and younger women. The highly educated female migrants today include the so-called "Eurocrats" who work in EU institutions (Bajuk Senčar 2014), researchers and experts. According to a study by Milena Bevc, in the period between 1995 and 2009, 43 percent of all highly educated emigrants were women, who mostly emigrated to the US, Germany, Austria and the Netherlands (Bevc 2013).

\section{Researching gender and the experiences of women migrants in Slovenian emigration}

How did the awareness about and research of Slovenian women emigrants and gendered migration develop? I have found that we did not substantially lag behind the world trends in terms of when we began to study female migration and the significance of gender as an important factor in migration processes, only the funding and consequently the scope of the studies were and are significantly smaller. At the Slovenian Migration Institute at the Research Centre of the Slovenian Academy of Sciences and Arts (ZRC SAZU), we began our initial research focusing exclusively on Slovenian women emigrants in 2001. The research project entitled "The Role and the Significance of Women in the Preservation of Cultural Tradition among Emigrants" was a three-year basic research project funded by the Slovenian Research Agency. ${ }^{4}$ The results of studying women in Slovenian emigration and migration were copious and multifaceted. The research project included various activities ranging from fieldwork in various thematic and geographical areas to the analysis of archival material and personal "documents of life" ${ }^{\prime \prime}$ and the first public scientific discussion addressing

3 The 1971 census recorded 48,000 temporary migrant workers from Slovenia, which is 2.8 percent of the population. Ten years later, the number decreased by 10,000 , while the number of family members increased. The largest number of temporary migrant workers went to German-speaking European countries (Statistical Yearbook of the Socialist Republic of Slovenia 1972-1989).

4 The project leader was Marina Lukšič Hacin.

5 This is a term that Plummer (2001) used to illustratively name research sources such as diaries, correspondence, testimonies, life stories etc. 
the role of women in Slovenian emigration. A conference entitled "Women in Minority Communities: The Significance and the Role of Women in Preserving Cultural Tradition" was held in Ljubljana in June 2002 (Lukšič Hacin 2002).

The conference showed that a few researchers had already studied female migration two decades earlier. Their efforts were extraordinary since no funding was available for studying either women or female migrations, but especially because they were entirely absent from historical and other scientific books, textbooks, exhibitions and review works. The pioneering work in the research of Slovenian female migration was conducted by Dorica Makuc, who published a book on the Alexandrian women in 1994, and Inge Miklavčič Brezigar, who continued Makuc's work as a curator and researcher (Barbič, Miklavčič Brezigar 1999). During the 1990s, Aleksej Kalc had researched the mass migration of women to Trieste in the $18^{\text {th }}$ and $19^{\text {th }}$ centuries and, at the conference, pointed out the structural determinants of gendered migration and the need to take into account the various complex temporal and geographical factors, trends and regional specifics in view of which male and female migration is different even when the destination is the same, in this case, Trieste (Kalc in Lukšič Hacin 2002: 153-154)

In view of the depth, breadth and exceptional relevance of his findings, Marjan Drnovšek, a historian at the Slovenian Migration Institute, stands out among the pioneers in the research of female migration in the context of Slovenian emigration. He joined the global trends of studying gendered migration and the proportion of women in migration processes at the very beginning, in the mid-1980s. Drnovšek studied Slovenian women emigrants in various temporal and geographical contexts, for example, Slovenian women emigrants in the Spanish Civil War (1988), in the US (1997) and in Egypt, but also many other cases, which I will discuss below. At the 2002 conference, he placed the consideration of female migration in the broadest social, political and ideological framework, emphasising that it does not involve merely the studying of the gender composition of migration, but also the examination of broader social issues and gender as an important analytical category within the research of Slovenian emigration and migrations:

In addition, I am interested in the woman (emigrant) question also in view of the attitudes of various authorities towards emigration in general and, in our context, the emigration of women. What I have in mind is the attitude of the state, the Church and political parties, taking into account various world views and ideological and political perspectives. [...] It is precisely in relation to the emigration of women that we encounter an interesting phenomenon related especially to Catholic wives, i.e. religious women or families, namely the "philosophy" that the husband is the head of the family, while the wife is its heart. (Drnovšek in Lukšič Hacin 2002: 175)

Drnovšek continued by pointing out the need to study (female) migration as family migration with the help of personal documents and intimate stories and also the 
need to focus research on migrant children: "Emigrant letters are exceptionally significant from all perspectives because they show precisely these family relations. Today, we are emphasising women, but I believe that we should discuss all this more in the context of families, that we generally talk little about children of both sexes, who are the most marginalised, including in the study of emigration issues" (ibid.). In the years that followed, the research of subjective experiences of migration processes based on narrations, testimonies, correspondence and other personal materials became one of the key conceptual and methodological orientations of the research conducted at the Slovenian Migration Institute, the Peace Institute and other institutions.

\section{METHODOLOGICAL APPROACHES AND CHALLENGES}

In the period after the publication of "Women in Migration" in 1984, two often intertwined approaches developed in the research of migration and gender, and female migration. The first involves determining the gender composition of migration and researching the structural, systemic determinants of female and male migration or the differences in the typologies of migration. The majority of studies from this period first focused on historically overlooked and unknown female migration processes and exclusively female experiences of migration. Studies in which women were the subject of the research while men were often overlooked as women had been in previous studies predominated. The second approach takes into account the view that migrations are a gendered phenomenon requiring more sophisticated conceptual and theoretical tools for the analysis of gendered power relations. It foregrounds the difference between sex and gender as a relational, fluid category that develops in the subjective process of identity construction, a category that was formed at the end of the $20^{\text {th }}$ century (Donato et al. 2006: 5). Gender is a way of structuring social power in all human relations, including between people in migration processes. It is related to other socially significant determinants of the hierarchy of power and discrimination, especially class and ethnicity or race, but also religion, education, age and sexual orientation. Gender should be understood as a structure of institutionalised social relations within which power and authority are organised, but at the same time also as a process of identification, "wherein gender identities, relations and ideologies are fluid, not fixed" (Pessar, Mahler 2003: 813).

The studies of female migration in Slovenia followed global trends, and gender became an important concept in migration research. In addition to historical research of typical female migrations and the gender composition of migration, researchers also took up the research of gendered migration in which gender was understood as a series of social relations that have an impact on migration processes and patterns. At the beginning of his research of female migration, Marjan Drnovšek studied it in the context of the hierarchy of control and domination of the 
Catholic Church and other political centres of power. He studied the political, ideological and social conditions of emigration in view of the impact that the relation between the sexes and the category of gender had on the migrations in the Slovenian ethnic territory in various political, state, administrative, economic and cultural contexts. He devoted his attention particularly to the attitude of the public towards female emigrants and suggested ways of researching this dynamic topic:

In short, the attitude towards female emigrants and their role in public life has to be considered in the context of the attitude towards women in emigrant and immigrant communities in general, taking into account the local/regional particularities and the time under consideration. In various periods, the attitude towards them, that is, towards their emigration or immigration, reflects - as we already mentioned - the attitude towards women in Slovenia in general, which could be encapsulated by the saying: "A wife should stay at home and wait for her husband." Catholic traditionalism in the views on family was also manifested in emigration in all periods (before World War One, between the two world wars and in the 1960s and 70s), as well as the present. (Drnovšek 2004: 385)

In the title of his 1997 article "America: A Paradise for Women", 6 Drnovšek pointed out the significance of migrations in the structural changing of sexual roles and the hierarchy of power. He described a rule that was later observed by numerous researchers of female migration: he noted a key characteristic of migration processes as a gendered process in the past, which still holds true today, i.e. the fundamental law that migrations transform, reorganise and restructure gender roles. To explain this phenomenon, Suzanne Sinke uses the concept of "social reproduction", which she defines as a "framework to describe a variety of roles in re-creating families, network, and communities" - the roles women in migration contexts had and still have (Sinke 2002: 6). In her historical analysis of Dutch female emigrants to "America", she found that social reproduction is the function of women who nourish, care, nurse and cherish their families, communities and ties, but they do not do this the old way, which they learned "on the other side". This activity is subject to constant considerations about changing and preserving, adapting and not adapting, conservativeness and innovation, which depend on numerous circumstances and personal needs. In the past, migration also brought women a greater variability of their roles compared to their original environment, especially if they migrated to the US. Donna Gabaccia notes that for the female migrants "the main challenge of migration was to claim new forms of power - whether in the form of an individual wage, the choice of a

6 In his paper on Slovenian female emigrants at the $32^{\text {nd }}$ Assembly of the Historical Association of Slovenia on the topic of women through history (Drnovšek 2004), Drnovšek cited this article and the following quotation from the newspaper Slovenka (Slovenian Woman) from 1900: "When our Slovenian girls begin to breathe the free American spirit, they too change." 
spouse, or leisure time - without losing older female modes of influence within community and kinship networks" (Gabaccia 1994: 134).

The studies that present today's female migrants in Europe as active (Passerini et al. 2007; Slany et al. 2010; Pajnik, Anthias 2014) also share the finding that, within the heterogeneity of female migration waves, the only common characteristic of women is that they can no longer be perceived as passive victims of circumstance, but are to be perceived as active in making the decision to change their life and to a large extent also their family's life. For women, migration has not been negative for a long time, and even though there are still conditions in which we cannot see any positive changes in the position of women, there are numerous circumstances in which women migrants gain in power, influence, significance, autonomy over their bodies, work and income and above all freedom they could not even imagine in their original environment (Anthias, Lazaridis 2000).

In the context of Slovenian women emigrants, Jernej Mlekuž and Marina Lukšič Hacin have intensively studied gender ideologies and hierarchies of power and discrimination. The latter placed Slovenian female emigrants in the context of the patriarchal social order and sex dichotomy (Lukšič Hacin 2003; 2009). In this context, she analysed the place of the Alexandrian women in the national collective memory (2015). Mlekuž presented gender in his discursive analysis of the press that, in different periods and places, covered the hired girls from Slavia Friulana and their "slave labour" in Italian towns (2009), the traditionally limited roles of women in the Slovenian diaspora in Argentina (2009a) and the public shaming of the Alexandrian women in the local environment on the western border of the Slovenian ethnic territory (2016). Some female historians also took up research of female migration from the perspective of gender as an analytical category (Strle 2009, Škrlj 2009). Marta Verginella (2011: 156) used the case of the Alexandrian women to illustrate the complexity of female migration and the changes in socially-prescribed gender roles which they inevitably lead to:

The first to write about women crossing social and national borders were travellers who visited Egypt, priests worried about the moral life of female emigrants, and later also politicians and municipal administrators dealing with the economic and administrative consequences of female emigration to Alexandria and Cairo. For nationalistic men who supported the image of a "loving and caring wife and mother", the wet nurses from Primorska in particular were a source of great shame because they had left their own children to feed foreign ones. From the viewpoint of the defenders of national interests, the women who had left for Egypt crippled the "nation's defensive power". In the absence of family and village supervision, the foreigners could seduce and dishonour them. Abroad, even the most virtuous girls and wives could become women of ill repute. 
Of all the Slovenian female emigrants, the Alexandrian women are doubtlessly the most thoroughly researched phenomenon. Intensive research began in 2005 with the foundation of the Society for the Preservation of the Cultural Heritage of the Alexandrian Women and the Museum of Alexandrian Women in Prvačina a year later. From the local environment, where an affirmative commemoration of the Alexandrian women emerged in the form of collecting tangible and intangible heritage and organising exhibitions, performances and events, the interest spread to the state level. The phenomenon of the Alexandrian women was taken up by Daša Koprivec, a curator at the Slovenian Ethnographic Museum, who provided professional and research assistance to everyone who began studying their families' stories in the local environment. In her research, publications and a scientific monograph, Koprivec managed, at the last possible moment, to collect the testimonies and memories of personal, family and collective experiences of female migration from Goriška to North Africa (Koprivec 2006; 2013).

Early on, the research of female migration began using the method of oral history or the biographical method. The "documents of life" such as diaries, letters, postcards, life stories, testimonies and memories became an important source for the research of the subjective experiences of migration processes not only among the female emigrants themselves, but also their family members. The already mentioned first project of the Slovenian Migration Institute, "The Role and the Significance of Women in the Preservation of Cultural Tradition among Emigrants" was based on this methodology. With the subsequent projects of studying memories and identity, the researchers produced a few key works on female migration and the significance of gender in researching Slovenian emigration, such as Krila migracij (a double entendre meaning both "The Wings of Migration" and "The Skirts of Migration", Milharčič Hladnik, Mlekuž 2009), which includes individual life stories and gender analyses in the migration context of female emigrants (Pepica in the US, Stanka in Canada, an Alexandrian woman in Egypt), a wife and mother who stayed at home when her husband left for Belgium to work in the mines there and female immigrants (Bosniak women in Slovenia, immigrants from the former Soviet Union and refugees from Bosnia and Herzegovina); Go Girls! When Slovenian Women Left Home (Lukšič Hacin 2009); and Going Places, Slovenian Women's Stories on Migration (Milharčič Hladnik, Mlekuž 2014). Using the biographical method, the research results presented Slovenian women emigrants as a heterogeneous category and Slovenian female emigration as a kaleidoscope of individual, diverse, dynamic and changing life stories about the construction of national, ethnic and gender identities (Milharčič Hladnik 2004); complex family decisions and everyday negotiations in transnational networks of support and maintaining contacts; and the emotional dynamics of departing, returning or living in a foreign world, which in most cases was much more respectful towards and considerate of Slovenian women emigrants than the Slovenian patriarchal environment, with its high degree of church and family control and the suppression of women's ambitions and desires for change (Škrlj 2009). But, 
above all, the selected methodology made it possible for the numerous texts, books and presentations of research results to bring out the voices, stories and experiences of women who until then had not existed in the collective memory and the scientific arsenal of the study of national and transnational history.

In the context of Slovenian female emigration, the public image of women emigrants in Slovenia and their activity in emigrant communities, many authors have analysed gender as a relational, fluid category that develops in a subjective process of identity construction. In addition to Daša Koprivec and the editors of the abovementioned books, Marjan Drnovšek also examined individual stories of women emigrants with the help of personal documents and testimonies and thus, among others, presented the fate of Liza, a cook in New York (2001), and the letter of Apolonija Noč from St. Joseph, Minnesota (1855) (2003a); Irena Gantar Godina (2009) researched the migrant paths of educated Slovenian women; Breda Čebulj Sajko (2005) presented the life of Mariza Ličen, while Mirjam Milharčič Hladnik (2007) traced the activities and thoughts of Marie Prisland, the founder of the Slovenian Women's Union of America, to mention only a few.

\section{EMIGRATION IN VIEW OF IMMIGRATION}

In the last four decades, Slovenia, like many other European countries, has changed from a country of emigration to a country of immigration, which is also reflected in the studies of gendered migrations. The feminisation of migrations, sex work and the trafficking of women was researched by Mojca Pajnik (2008), one of the leading researchers of gendered migration, who together with her colleague Veronika Bajt co-authored important texts on female migration in the context of transnationalism (Pajnik, Bajt 2012), the labour market in Slovenia (2013) and the use of the biographical method in studying women's experiences of migration (Pajnik, Bajt 2009). ${ }^{7}$ In the last decade, we have seen several studies use biographical methods to research gendered migrations in Slovenia, refugees and the position of the descendants of immigrants and asylum seekers. Špela Razpotnik studied the identity constructions of young women immigrants (Razpotnik 2004), while Sanja Cukut Krilić (2009) ${ }^{8}$ analysed the personal experiences of women migrants from Bosnia and Herzegovina and the Soviet Union in Slovenia before and after 1991 based on collected life stories. Milica Antić Gaber (2011) edited Na poti do lastne sobe (On the Way to a Room of One's Own), a collection of life stories of women immigrants (and their descendents) living in Slovenia in various periods since the mid- $20^{\text {th }}$ century. Tjaša Učakar critically reviewed

7 Both researchers work at the Peace Institute, which has carried out several basic research projects on gendered migration in Slovenia.

8 Sanja Cukut Krilić has also made a detailed survey of the works and studies that deal with gendered migrations from the emigration and immigration perspectives and were published in Slovenia (Cukut Krilič 2009: 76-81). 
these numerous and diverse research efforts as follows: "A few studies on female migration have already been carried out in Slovenia although some used gender merely as a separate category and not as an explanatory concept with a broader influence on other social factors" (Učakar 2014: 173). She assessed the research on women migrants that has been conducted in Slovenia to date in the framework of the latest fundamental research project on the specific topic of female migration, which was funded by the Slovenian Research Agency (2011-2014). ${ }^{9}$ Just as in the last few decades the research of subjective experiences of migration processes based on narration, testimonies, correspondences and other personal material has become one of the key conceptual and methodological directions in the research of female migration and women migrants conducted at various institutions, this research too focuses on personal experiences, subjective perceptions and intimate stories of female emigrants and immigrants. Ksenija Vidmar Horvat (2014: 11-12) described this key connection between emigrant and immigrant aspects of female migration in the Slovenian ethnic territory as

a specific case study: experiences shared by Slovene female migrants in many ways formed a culturally specific migrant biography, i.e., a biography that is defined by a particular cultural, mental and physical geography of (forced and voluntary) travel across the border of a historically concrete national collective. At the same time, this biography entwines with the broader global experience of women as migrants who, in addition to (or in parallel with) the national, also challenge, disturb and destabilize other social geographies, such as those of gender, generation, emotions, economy, ethno-racial categories etc. Here we witness the formation of a biography of a female migrant whose fate is determined less by national and more by transnational positioning within structures of power and belonging; and who is more than by moralistic discourses of her home society affected by Orientalist and economic (neoliberal) discourses of globalised host, foreign nations.

In the context of gendered migration processes, in the future we hope to see even more research approaches that understand the inseparability of the emigration and immigration aspects of migrations and that conceptually connect the stories and the experiences of those that leave and those that come. In this sense, the particular aspect of forced migration deserves more research attention. In recent years there have been some attempts to historically and conceptually evaluate Slovenian women's forced migration, deportation, relocation and refugee experiences during the First and Second World Wars (Verginella 2013, Strle 2013; 2016). These findings and analyses should be included in all research projects and books on Slovenian emigration in order to finally bring different aspects of the forced migration of Slove-

9 The project entitled "The role of Migration and Female Migrants in the Construction of Slovene National Identity from the National to the Post-National Era" was headed by Ksenija Vidmar Horvat of the Faculty of Arts at the University of Ljubljana. 
nian women to scholarly and wider public attention. However, in the wake of the contemporary refugees who are seeking safety in Slovenia and Europe there is also an urgent need to pay attention to the gender dimension in forced migration to Slovenia in historical and contemporary perspective. Some researchers have already done important work on previous women refugee experiences, especially during the 1990s (Cukut Krilič 2009) but there are new challenges with the latest "refugee crisis" in Europe and Slovenia that require a prompt response in research attempts to record the experiences of women refugees and to analyse the gender dimension of their social and cultural trajectories.

\section{REFERENCES}

Anthias, Floya, Lazaridis, Gabriella (ed.) (2000). Gender and Migration in Southern Europe: Women on the Move. Oxford, New York: Berg.

Bajuk Senčar, Tatiana (2014). Eurocrats in Brussels: Contemporary Career Women. Going Places: Slovenian Women's Stories on Migration (eds. Mirjam Milharčič Hladnik, Jernej Mlekuž). Akron: Akron University Press, 213-234.

Barbič, Ana, Inga Miklavčič Brezigar (1999). Domestic Work Abroad: A Necessity and an Opportunity for Rural Women from the Goriška Borderland Region of Slovenia. Gender, Migration and Domestic Service (ed. Janet H. Momsen). London: Routledge, 164-178.

Bevc, Milena (2013). Emigracija slovenskih znanstvenikov v obdobju 1995-2009 po njihovem znanstvenem področju. Dve domovini / Two Homelands 37, 21-40.

Cukut Krilić, Sanja (2009). Spol in migracija: Izkušnje žensk kot akterk migracij. Ljubljana: Založba ZRC SAZU.

Čebulj Sajko, Breda (2005). Mariza Ličan: Sledi življenja izseljenke. Dve domovini /Two Homelands 21, 143-162.

Donato, Katharine M., Gabaccia, Donna, Holdaway, Jennifer, Manalansan, Martin, Pessar, Patricia R. (2006). A Glass Half Full? Gender in Migration Studies. International Migration Review 40/1, 3-26.

Donato, M. Katharine, Gabaccia, Donna (2015). Gender and International Migration: From the Slavery Era to the Global Age. New York: Russell Sage Foundation.

Drnovšek, Marjan (1988). Slovenske izseljenke iz Pas de Calaisa (Francija) in španska državljanska vojna. Slovenski koledar '89 (ed. Jože Prešeren). Ljubljana: Slovenska izseljenska matica, 105-108.

Drnovšek, Marjan (1997). Amerika: Raj za ženske. Zgodovina za vse 2, 22-25.

Drnovšek, Marjan (2001). Kuharica Liza v New Yorku. Izseljenec: Življenjske zgodbe Slovencev po svetu (exhibition catalogue). Ljubljana: Muzej novejše zgodovine, 43-46. 
Drnovšek, Marjan (2002). Diskusijski prispevek - Ženska v manjšinskih skupnostih: Pomen in vloga žensk za ohranjanje kulturnega izročila. Dve domovini / Two Homelands 16, 173-175.

Drnovšek, Marjan (2003). Emigration of Slovene Women: A Short Historical View. Dve domovini / Two Homelands 17, 29-46.

Drnovšek, Marjan (2003a). Pismo Apolonije Noč od Sv. Jožefa/St. Joseph, Minnesota (1855). Dve domovini / Two Homelands 18, 63-81.

Drnovšek, Marjan (2004). Izseljenke v očeh javnosti. Ženske skozi zgodovino: Zbornik referatov 32. zborovanja slovenskih zgodovinarjev (ed. Aleksander Žižek). Celje: Zveza zgodovinskih društev Slovenije, 383-393.

Ehrenreich, Barbara, Hochschield, Arlie Russel (ed.) (2003). Global Woman: Nannies, Maids, and Sex Workers in the New Economy. New York: Metropolitan Books.

Gabaccia, Donna (1994). From the Other Side: Women, Gender, and Immigrant Life in the U.S. 1820-1990. Bloomington, Indianapolis: Indiana University Press.

Gaber Antić, Milica (ed.) (2011). Na poti do lastne sobe. Ljubljana: i2.

Gantar Godina, Irena (2009). "Žensko znanstveno delo je za človeško družbo namreč brez vsake koristi ...": Slovenske izobraženke in umetnice med ožjo in širšo domovino (do 1921). Dve domovini / Two Homelands 30, 155-173.

Hrženjak, Majda (2014). Globalizacija skrbstvenega dela in položaj primorskih skrbstvenih delavk v Italiji. Dve domovini / Two Homelands 40, 57-70.

Kalc, Aleksej (2004). Žensko prebivalstvo v Trstu leta 1775: Nekaj socialno-demografskih in gospodarskih vidikov ter metodoloških vprašanj. Zgodovinski časopis 3-4, 337-376.

Kalc, Aleksej (2002). Diskusijski prispevek - Ženska v manjšinskih skupnostih: Pomen in vloga žensk za ohranjanje kulturnega izročila. Dve domovini / Two Homelands $16,165-166$.

Koprivec, Daša (2006). Aleksandrinke: Življenje v Egiptu in doma. Etnolog 16/67, 97-115.

Koprivec, Daša (2013). Dediščina aleksandrink in spomini njihovih potomcev. Ljubljana: Založba ZRC.

Lukšič Hacin, Marina (eds.) (2002). Ženske v manjšinskih skupnostih: Pomen in vloga žensk za ohranjanje kulturnega izročila. Dve domovini / Two Homelands 16, 141-208.

Lukšič Hacin, Marina (2003). Vloga izseljenk za ohranjanje nacionalne identitete v kontekstih, ki jih konstituirajo patriarhalni odnosi in spolna dihotomija. Dve domovini / Two Homelands 18, 97-112.

Lukšič Hacin, Marina (2009). Concealment and Patriarchy, Man is an Idea, Woman is Matter; Man is a Head, Woman is a Heart. Go Girls! When Slovenian Women Left Home (eds. Marina Lukšič Hacin, Jernej Mlekuž). Ljubljana: Založba ZRC, ZRC SAZU, 63-87.

Lukšič Hacin, Marina, Mlekuž, Jernej (eds.) (2009). Go Girls! When Slovenian Women Left Home. Ljubljana: Založba ZRC, ZRC SAZU. 
Lukšič Hacin, Marina (2015). Women Migrants and Gender Relations: Patriarchy in the Time of Aleksandrinke. From Slovenia to Egypt: Aleksandrinke's Trans-Mediterranean Domestic Workers' Migration and National Imagination (ed. Mirjam Milharčič Hladnik). Gottingen: V \& R unipress, 157-171.

Makuc, Dorica (1994). Aleksandrinke. Gorica: Goriška Mohorjeva družba.

Milharčič Hladnik, Mirjam (2004). Ohranjanje etnične identitete in tradicije med slovenskimi izseljenci in njihovimi potomci v Združenih državah Amerike. Dve domovini / Two Homelands 19, 121-139.

Milharčič Hladnik, Mirjam (2007). Marie Prisland - her Role in Preserving Slovenian Culture and Tradition among Slovenian Migrants in the United States. Dve domovini / Two Homelands 25, 229-247.

Milharčič Hladnik, Mirjam, Mlekuž, Jernej (eds.) (2009). Krila migracij: Po meri življenjskih zgodb. Ljubljana, Založba ZRC, ZRC SAZU.

Milharčič Hladnik, Mirjam, Mlekuž, Jernej (eds.) (2014). Going Places: Slovenian Women's Stories on Migration. Akron: Akron University Press.

Milharčič Hladnik, Mirjam (eds.) (2015). From Slovenia to Egypt: Aleksandrinke's Trans-Mediterranean Domestic Workers' Migration and National Imagination. Gottingen: V \& R unipress.

Mlekuž, Jernej (2004). Izbrani vidiki zaposlovanja beneških deklet v gospodinjstvih italijanskih mest: Tiha, grenko-sladka, nikoli povsem izrečena in slišana zgodba. Dve domovini / Two Homelands 19, 141-164.

Mlekuž, Jernej (2009). Maledet? Schiavitu? Ko oblastni glas utihne. Krila migracij: Po meri življenjskih zgodb (eds. Mirjam Milharčič Hladnik, Jernej Mlekuž). Ljubljana: Založba ZRC, ZRC SAZU, 121-142.

Mlekuž, Jernej (2009a). Housewife, Wife, and Mother: Three Roles that the Creator Ensconed in Women's Hearts. Go Girls! When Slovenian Women Left Home (eds. Marina Lukšič Hacin, Jernej Mlekuž). Ljubljana: Založba ZRC, ZRC SAZU, 87-108.

Mlekuž, Jernej (2016). Aleksandrinke kot nosilke časti narodne skupnosti v dopisu Karola Pečnika iz Egipta (1897). Dve domovini / Two Homelands 43, 143-156.

Pajnik, Mojca (2008). Prostitucija in trgovanje z ljudmi: Perspektive spola, dela in migracij. Ljubljana: Mirovni inštitut.

Pajnik, Mojca, Bajt, Veronika (2009). Biografski narativni intervju: Aplikacija na študije migracij. Dve domovini / Two Homelands 30, 69-89.

Pajnik, Mojca, Bajt, Veronika (2012). Migrant Women's Transnationalism: Family Patterns and Policies. International Migration 50/5, 153-168.

Pajnik, Mojca, Bajt, Veronika (2013). Migrant Women's Work: Intermeshing Structure and Agency. Ars \& Humanitas VII/2, 163-176.

Pajnik, Mojca, Anthias, Floya (eds.) (2014). Work and the Challenges of Belonging: Migrants in Globalizing Economies. Newcastle upon Tyne: Cambridge Scholars Publishing.

Passerini, Louisa et al. (ed.) (2007). Women Migrants from East to West, Gender, Mobility and Belonging in Contemporary Europe. New York, Oxford: Berghan Books. 
Pessar, Patricia R., Mahler, Sarah J. (2003). Transnational Migration: Bringing Gender In. International Migration Review 37/3, 812-846.

Plummer, Ken (2001). Documents of Life 2, An Invitation to a Critical Humanism. London, Thousands Oaks, New Delhi: Sage Publications.

Ravenstein, Ernst G. (1885). The Laws of Migration. Journal of the Royal Statistical Society 48/2, 167-235.

Razpotnik, Špela (2004). Preseki odvečnosti: Nevidne identitete mladih priseljenk v družbi tranzicijskih vic. Ljubljana: Pedagoška fakulteta.

Roškar, Saša (2014). Slamnikarice Abroad and at Home: Ladies and Entrepreneurs. Going Places: Slovenian Women's Stories on Migration (eds. Mirjam Milharčič Hladnik, Jernej Mlekuž). Akron: Akron University Press, 171-212.

Rowbotham, Sheila (2001). Foreword. Women, Gender and Labour Migration: Historical and Global Perspectives (ed. Pamela Sharpe). London, New York: Routledge, $x v i-x v i i$.

Sinke, Suzanne M. (2002). Dutch Immigrant Women in the United States, 1880-1920. Urbana, Chicago: University of Illinois Press.

Slany, Krystyna, Kontos, Maria, Liapi, Maria (eds.) (2010). Women in New Migrations: Current Debates in European Societies. Krakov: Jagiellonian University Press.

Strle, Urška (2009). Bila je preprosto sreča, da sem prišla v Kanado. Krila migracij: Po meri življenjskih zgodb (eds. Mirjam Milharčič Hladnik, Jernej Mlekuž). Ljubljana: Založba ZRC, ZRC SAZU, 89-117.

Strle, Urška (2013). Begunke v slovenskem delu Kraljevine (1918-1941). Dolga pot pravic žensk: Pravna in politična zgodovina žensk na Slovenskem (ed. Marta Verginella). Ljubljana: Znanstvena založba Filozofske fakultete, Studia humanitatis,159-184.

Strle, Urška (2016). Begunke in velika vojna na Slovenskem. Begunci: Slovenski begunci s soške fronte (eds. Ines Beguš, Marko Klavora, Katarina Brešan). Nova Gorica: Goriški muzej, 44-51.

Statistični letopis SR Slovenije 1972-1989 (1990). Ljubljana: Zavod SR Slovenije za statistiko.

Škrlj, Katja (2009). Komaj sem čakala, da zrastem in postanem aleksandrinka. Krila migracij: Po meri življenjskih zgodb (eds. Mirjam Milharčič Hladnik, Jernej Mlekuž). Ljubljana: Založba ZRC, ZRC SAZU, 143-189.

Učakar, Tjaša (2014). Dom, domovina in identiteta: Priseljenke v slovenskem prostoru. Ženske na poti, ženske napoti: Migrantke v slovenski nacionalni imaginaciji. Women Away, Women on the Way: Female Migrants in the Slovene national Imagination (ed. Ksenija Vidmar Horvat). Ljubljana: Filozofska fakulteta, 169-188.

Verginella, Marta (2011). Aleksandrinke med mitom in resničnostjo. Le rotte di Alexandria / Po aleksandrijskih poteh (eds. Franco Pero, Patrizia Vascotto). Trst: EUT, 163-176.

Verginella, Marta (2013). Profughe slovene tra Grande Guerra e ascesa del fascismo. Storia delle done 9, 135-159. 
Vidmar Horvat, Ksenija (ed.) (2014). Ženske na poti, ženske napoti: Migrantke v slovenski nacionalni imaginaciji. Women Away, Women on the Way: Female Migrants in the Slovene national Imagination. Ljubljana: Filozofska fakulteta.

Vidmar Horvat, Ksenija (2014). Predgovor: Ženskam naproti. Ženske na poti, ženske napoti: Migrantke $v$ slovenski nacionalni imaginaciji (ed. Ksenija Vidmar Horvat). Ljubljana: Filozofska fakulteta, 7-11.

Women in Migration (1984). Special Issue - International Migration Review 18/4.

Žižek, Aleksander (ed.) (2004). Ženske skozi zgodovino: Zbornik referatov 32. zborovanja slovenskih zgodovinarjev. Ljubljana: Zveza zgodovinskih društev Slovenije.

Žitnik Serafin, Janja, Kalc, Aleksej (eds.) (2017). Raziskovanje slovenskega izseljenstva: Vidiki, pristopi, vsebine. Ljubljana: Založba ZRC, ZRC SAZU. 


\section{POVZETEK}

\section{RAZISKOVANJE SLOVENSKEGA IZSELJENSTVA V LUČI SPOLNO OBELEŽENIH MIGRACIJ Mirjam MILHARČIČ HLADNIK}

Članek opisuje do zdaj raziskane značilnosti ženskih migracij ter poti raziskovanja slovenskih izseljenk oziroma spolno obeleženih migracij. Prikazuje, kako so se v procesu odkrivanja zgodovinske in sodobne prisotnosti žensk v migracijah ter z upoštevanjem spola kot družbenega generatorja razmerij moči in diskriminacije tako $v$ svetu kot pri nas številne discipline obogatile, izoblikovali pa so se tudi številni interdisciplinarni metodološki pristopi in povezave. Avtorica ugotavlja, da začetki raziskovanja ženskih migracij ter pomena spola kot dejavnika migracijskih procesov pri nas niso zaostajali za svetovnimi trendi, le financiranje in posledično obseg raziskav sta (bila) bistveno manjša. Navaja vodilne raziskovalce in raziskovalke ter kompleksnost raziskovalnih tematik, ki so jih zastavljali že v osemdesetih letih prejšnjega stoletja, in se osredotoča na tiste metodološke pristope, ki so pomenili odločilen zasuk v raziskovanju ženskih migracij in migracij nasploh. Raziskovanje subjektivnih izkušenj migracijskega procesa na podlagi pripovedi, pričevanj, korespondenc in drugih osebnih gradiv je na Inštitutu za slovensko izseljenstvo in migracije ZRC SAZU, Mirovnem inštitutu, Filozofski fakulteti in tudi drugih institucijah postalo eno ključnih konceptualnih in metodoloških raziskovalnih usmeritev. Pomemben premik v razvoju migracijskih študij pri nas je prinesla - tako z zgodovinskega kot s sodobnega stališča - tudi konceptualna združitev raziskovanja izseljevanja iz Slovenije in priseljevanja v Slovenijo. Raziskovalne pristope, ki upoštevajo nerazdružljivost izseljenskih in priseljenskih vidikov migracij in ki konceptualno povezujejo zgodbe in izkušnje tistih, ki odhajajo, in tistih, ki prihajajo, je treba v kontekstu spolno obeleženih migracijskih procesov dopolniti z raziskavami prisilnih migracij, prebežništva in begunstva. To je še zlasti pomembno v času po t. i. »begunski krizi« 2015-2016, ko je poznavanje lastne zgodovine begunstva in prebežništva postalo temelj za razumevanje sodobnih fenomenov prisilnih migracij. 